\title{
Addressing vulnerabilities of female sex workers in an HIV prevention intervention in Mumbai and Thane: experiences from the Aastha project
}

\author{
This article was published in the following Dove Press journal: \\ HIV/AIDS - Research and Palliative Care \\ 19 February 2014 \\ Number of times this article has been viewed
}

\section{Virupax Ranebennur' Sanjeevsingh Gaikwad' Sowmya Ramesh ${ }^{2}$ \\ Amrita Bhende'}

'FHI 360, Maharashtra, Mumbai, India; ${ }^{2}$ HIVIAIDS Programs, Population Council, New Delhi, India
Correspondence: Virupax Ranebennur FHI 360, Maharashtra, 704-705 Balarama Building, Bandra-Kurla Complex, Bandra East, Mumbai 40005I, India

Tel +9l 2266750457

Fax +9I 2226592344

Email vranebennur@fhi360.org
Background: It is important for targeted interventions to consider vulnerabilities of female sex workers (FSWs) such as poverty, work-related mobility, and literacy, for effective human immunodeficiency virus (HIV) prevention. This paper describes and examines the association of the Aastha HIV/sexually transmitted infection (STI) prevention project in Mumbai and Thane, India, on the relationship between vulnerability and behavioral outcomes.

Materials and methods: Data were drawn from the Behavioural Tracking Survey, a crosssectional behavioral study conducted in 2010 with 2,431 FSWs recruited in Mumbai and Thane. The key independent measures used were program exposure and "vulnerability index", a composite index of literacy, factors of dependence (alternative livelihood options, current debt, and children), and aspects of sex work (mobility and duration in sex work). Dependent measures included service uptake, self-confidence, self-identity, and individual agency. Logistic regression analysis was used to examine the study objectives.

Results: Of the analytical sample of 2,431 FSWs, 1,295 (53.3\%) were categorized as highly vulnerable. Highly vulnerable FSWs who were associated with the Aastha program for more than a year were more likely to have accessed crisis-response services in the past 6 months (adjusted odds ratio [AOR] 2.2, 95\% confidence interval [CI] 1.4-3.6; $P<0.001)$, to have visited a clinic to get a checkup for STI symptoms (AOR 2.4, 95\% CI 1.2-4.8; $P<0.015$ ), not to be ashamed to disclose identity as an FSW to health workers (AOR 2.1, 95\% CI 1.2-3.5; $P<0.008$ ), and to be confident in supporting a fellow FSW in crisis (AOR 1.7, 95\% CI 1.0-2.8, $P<0.033$ ) compared to those less vulnerable with similar exposure to the Aastha program.

Conclusion: It is critical for HIV/STI interventions to consider vulnerabilities of FSWs at project inception and address them with focused strategies, including a segmented servicedelivery model and community involvement, in order to strengthen the structural response to HIV prevention.

Keywords: HIV, vulnerability, FSWs, India, prevention

\section{Background}

Various studies have shown a shift in focus from condom programming and provision of clinical services to initiatives that address the contextual factors underlying human immunodeficiency virus (HIV) risk and vulnerability ${ }^{1}$ among high-risk groups. The Aastha project, funded by the Bill and Melinda Gates Foundation, a scaled-up HIVprevention intervention since 2004 to date across Mumbai and Thane with a heterogeneous population of sex workers in an urban setting, is a case in point. ${ }^{2,3}$ Even though Maharashtra is a high-prevalence state, the number of new infections in Mumbai has 
been reduced as a result of this intervention. ${ }^{4}$ One of the Aastha strategies has been to focus on the vulnerabilities of female sex workers (FSWs), and identifying what makes them vulnerable and redress mechanisms. Power dynamics play a crucial role in the sex industry and in the lives of FSWs, right from the scope of negotiation with clients and partners on condom use and sexual acts and managing the control and influence of stakeholders, such as brothel owners, bar owners, brothel managers, and local thugs. However, what makes some FSWs more vulnerable than others? And what implications do their sociocultural vulnerabilities have for an $\mathrm{HIV} /$ sexually transmitted infection (STI)-intervention program, whose prime objective is to encourage healthseeking behavior among FSWs? This paper postulates that it is the continuous interaction of various socioeconomic factors and aspects of sex work itself that together contribute toward making FSWs vulnerable, and some FSWs more than others. $^{3}$ The paper also argues that it is important for targeted interventions to define the "vulnerability" of their target group prior to project design and implementation, given that factors shaping vulnerability are context-specific and project strategies need to respond accordingly. Recently, through various syndemics, it has become increasingly clear that diseases do not occur in isolation, and social conditions of those who are suffering from these diseases are important factors to consider in order to understand the health impact on these individuals. ${ }^{5}$ Prior research highlights that some groups in society are more vulnerable to diseases than others. A set of social and economic factors appear to be associated with ideas, attitudes, and behaviors. ${ }^{5}$

\section{Defining vulnerability}

In an attempt to clarify the concept of vulnerability, Delor and Hubert describe it as relational, contextual, and the process aspect of risk. It thus has three coordinates: the risk of being exposed to crisis situations (exposure), the risk of not having the necessary resources to cope with these situations (capacity), and the risk of being subjected to serious consequences as a result of the crises (potentiality). ${ }^{6}$ However, it is important to make a distinction between HIV risk - behaviors or situations that directly increase the probability of HIV transmission - and HIV vulnerability, the social context that governs the individual's ability to avoid HIV transmission. ${ }^{1}$ Qualitative approaches to understanding the vulnerability of FSWs have looked upon integrated structural intervention strategies to reduce vulnerability among FSWs. ${ }^{7-9}$ For instance, a previous qualitative research study on the sociocultural context of FSWs in Nigeria suggested that five areas determine the degree of vulnerability, namely flawed knowledge, the psychosocial and economic context of sex work, stigma and risk-taking behavior, barriers to HIV testing, and legal constraints. ${ }^{8}$ However, there is a lack of similar quantitative analyses where the concept of vulnerability has been used as an independent measure. This paper contributes to the existing body of knowledge in this aspect by defining vulnerability and considering specific aspects.

Recent studies have explored the role of various factors separately, such as poverty, illiteracy, duration in sex work, and mobility for work among FSWs, contributing toward HIV vulnerability. In a study in the four high-prevalence Indian states, including Maharashtra, a higher degree of mobility was associated with higher rates of inconsistent condom use with clients and regular partners. ${ }^{10,11}$ Lack of social support in destination areas, changing environments that influence the sex worker's daily life, such as shifts in laws, changing police personnel, and high economic needs, make mobile FSWs especially vulnerable. ${ }^{7}$ Prior research that focused on the influence of socioeconomic factors on HIV risk and vulnerability suggests that women in India with less than 5 years of education had higher HIV prevalence compared to their counterparts, and that education has protective tendencies on HIV prevalence, as literacy is positively associated with comprehensive knowledge about HIV/acquired immunodeficiency syndrome (AIDS). ${ }^{12}$ In prior research that focused on the role of debt on HIV risk in a high-prevalence state in India, FSWs who reported debt were more likely to report recent violence, unprotected sex with occasional clients in the past week, and at least one STI symptom in the past 6 months. ${ }^{13}$

Previous research has also focused on preexisting sociocultural vulnerabilities that encourage FSWs to enter sex work in the first place. ${ }^{14}$ A microlevel study of the life circumstances of FSWs in Dimapur, Nagaland indicated the factors of vulnerability: 1) time of entry into sex work, ie, early age of sexual debut, lack of other sources of employment, low levels of education, and 2) factors of vulnerability in their current work situation, namely high levels of mobility, the need to financially support dependants, and the need to give money to others. ${ }^{15}$ In another study among mobile FSWs across Andhra Pradesh, Tamil Nadu, Karnataka, and Maharashtra, a significant association was seen between reasons for entry into sex work, such as poor economic conditions, and inconsistent condom use. Poor economic conditions were the primary reason for entry into sex work. ${ }^{14}$ These vulnerabilities increase FSWs' likelihood of experiencing violence, lead to poor negotiation skills with their clients, and act as a barrier to service utilization. ${ }^{16,17}$ It is evident from the aforementioned examples that frequently 


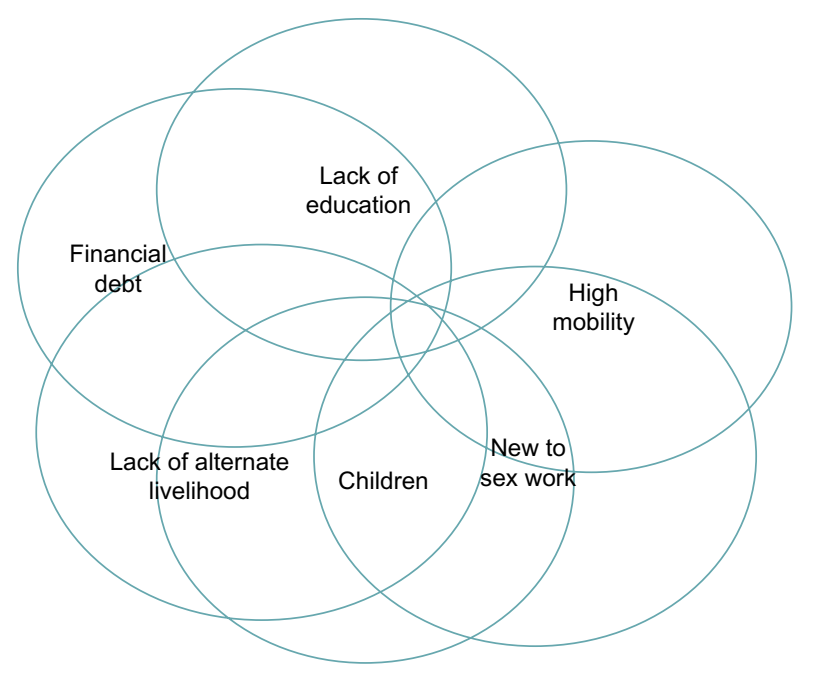

Interaction between factors of vulnerability

Figure I Interface of the factors of vulnerability.

one or two vulnerability factors have been considered in isolation, ${ }^{8-15}$ but as explained in the literature about various syndemics, ${ }^{5,18}$ vulnerability factors do not occur in isolation. Figure 1 illustrates the interaction and interface of various factors of vulnerability, which lead to differing degrees and types of vulnerability. There is a need to bring together individual factors to construct an index that considers all the important vulnerability factors. Therefore, this paper attempts: 1) to define vulnerability as an independent measure, after consolidating various independent factors; 2) to describe the Aastha HIV/STI prevention program, considering the vulnerabilities of FSWs prior to initiating the intervention; and 3) to understand the association of duration of exposure to the Aastha program on the relationship between vulnerability and behavioral outcomes.

\section{The Aastha project}

The Aastha HIV/STI prevention program was initiated in 2004 to reach out to FSWs who come from a diverse sociocultural background, predominantly from Andhra Pradesh, Karnataka, West Bengal, and Nepal, operating through various locations scattered across Mumbai and Thane. The project witnessed a high churn rate, as the FSWs that the project worked with were a highly mobile group. They also functioned from a wide range of places of solicitation: homes, streets, bars, brothels, and phone networks. The objective of the project was to empower FSWs to access and manage HIV-prevention services. A key focal area of the program was $100 \%$ screening for STIs, and the program achieved a $35 \%-40 \%$ monthly clinical uptake and up to $93 \%$ on a quarterly basis.
Table 1 gives a profile of the FSWs, in terms of the unique characteristics of each typology, the challenges faced while working with them, and the specially designed Aastha response. Through the program, interactive sessions are organized with FSWs to understand their vulnerabilities. During these sessions, various situations faced by FSWs that increased their vulnerability to HIV risk are discussed. These vulnerabilities affect their ability to seek health services, use condoms consistently, and address issues related to negotiation for safer sex behaviors, which in turn have an effect on the overall health of the FSWs, including increased chances of acquiring HIV infection.

During program implementation, we found that several issues were common to FSWs across typologies. Some of these included poor economic conditions, high degree of control and influence from partners and clients, lack of identity, low self-esteem and self-confidence, and lack of basic opportunities, such as schooling for FSWs' children and government identity cards, among others. The root cause for such common issues lay in the fact that each FSW was socially functioning alone in her given individual context. These vulnerabilities further manifested in increased cases of violence and harassment from stakeholders and regular partners, police arrests based on false charges, inconsistent condom use and a high transaction-frequency rate.

The Aastha project introduced strategies to empower FSWs and increase their self confidence in order to improve their health-seeking behavior and condom-negotiation skills with clients. The project created a self-help group called Aastha Gats at the local level. The Aastha Gats members promoted unity among FSWs to address issues related to the community. Details of this process are available elsewhere. ${ }^{2}$ In addition, the program initiated a community-led rapid-response system or Aastha Tatkal Seva (ATS) to tackle the regular violence faced by the FSWs. The ATS functions through site-level, sex worker-led groups that respond to crisis situations within 30 minutes. Further, the project also ensured that all FSW leaders in each hot-spot area were educated on the legal issues related to sex work and their rights as Indian citizens.

\section{Materials and methods}

The data for this study are drawn from the Behavioural Tracking Survey (BTS), ${ }^{2}$ a cross-sectional behavioral survey conducted in 2010 with 2,431 FSWs from 411 sites in Mumbai and Thane. Survey respondents included women who were $\geq 18$ years who had had sex in exchange of cash/ kind in the month prior to the survey. The Aastha project actively registers each FSW in all sites. For the survey, FSWs 
Table I FSW characteristics and vulnerability reduction strategies by typology of sex work under the Aastha project in Mumbai and Thane, India

\begin{tabular}{|c|c|c|c|}
\hline Typology & Characteristics of FSWs & Challenges & Aastha response \\
\hline $\begin{array}{l}\text { Brothel- } \\
\text { based }\end{array}$ & $\begin{array}{l}\text { Women who are paid for sex and reside } \\
\text { and solicit clients from a fixed place } \\
\text { (brothels) within the operational area } \\
\text { can be identified as brothel-based sex } \\
\text { workers. In a brothel, there are broadly } \\
\text { two kinds of sex workers: young girls } \\
\text { who are locally described as being "in } \\
\text { custody" and women who are "free". }\end{array}$ & $\begin{array}{l}\text { Most of them are controlled to varying degrees } \\
\text { by their gharwalis or madams, brothel owners, } \\
\text { pimps, and regular partners and look with } \\
\text { suspicion at "outsiders". Aastha staff have to } \\
\text { keep these work arrangements in mind while } \\
\text { attempting to reach each individual FSW. } \\
\text { The area witnesses a high incidence of police } \\
\text { arrests. }\end{array}$ & $\begin{array}{l}\text { Sensitization with brothel owners, } \\
\text { gharwalis and police. Introduction } \\
\text { of the ATS and increasing } \\
\text { knowledge on legal rights to } \\
\text { curtail arrests on false charges. } \\
\text { Exposure visits to police stations, } \\
\text { hospitals, banks, and schools to } \\
\text { build better links. }\end{array}$ \\
\hline $\begin{array}{l}\text { Bar-based or } \\
\text { bar girls }\end{array}$ & $\begin{array}{l}\text { Women who are paid for sex and } \\
\text { operate from discos and dance and } \\
\text { service bars and solicit clients, either at } \\
\text { their work or any other place within the } \\
\text { operational area. } \\
\text { They are commonly called bar girls. } \\
\text { When sexual services are offered, } \\
\text { customers are taken to rooms available } \\
\text { in nearby hotels. }\end{array}$ & $\begin{array}{l}\text { Bar girls are known not only for their high } \\
\text { mobility across bars but also for being under } \\
\text { the control of their bar managers, pimps, } \\
\text { and other stakeholders, so much so that the } \\
\text { entrances to these bars are always manned by } \\
\text { security personnel, who decide entry. } \\
\text { Also, bar girls are prone to increased } \\
\text { consumption of alcohol, leading to inconsistent } \\
\text { condom use. }\end{array}$ & $\begin{array}{l}\text { Regular meetings with bar } \\
\text { managers and owners to sensitize } \\
\text { them on issues of bar-based FSWs. } \\
\text { Selection of peer educators } \\
\text { from the same intervention site, } \\
\text { who form the bridge between } \\
\text { the project and the community } \\
\text { members. Formation of support } \\
\text { groups and creation of leaders } \\
\text { among them. }\end{array}$ \\
\hline $\begin{array}{l}\text { Street-based } \\
\text { or floating }\end{array}$ & $\begin{array}{l}\text { These are women who are paid for sex } \\
\text { and cruise from one place to another } \\
\text { or solicit clients at any suitable place } \\
\text { (lodges and/or pickup points) within } \\
\text { the operational area and are termed as } \\
\text { floating/street-based FSWs. Street-based } \\
\text { or floating FSWs stand in crowded places } \\
\text { near bus stops, railway stations, and } \\
\text { street corners to solicit clients. }\end{array}$ & $\begin{array}{l}\text { Street-based FSWs tend to lack access to } \\
\text { condoms, medical help, and information, as } \\
\text { well as face continuous harassment from local } \\
\text { thugs, other vendors, and police. This increases } \\
\text { their vulnerability to HIV infection. Further, } \\
\text { this group is difficult to intervene with on a } \\
\text { regular basis due to their mobile nature. }\end{array}$ & $\begin{array}{l}\text { Provision of legal literacy sessions } \\
\text { during support-group meetings. } \\
\text { Development of a strong ATS } \\
\text { to deal with cases of violence. } \\
\text { Specific training of the outreach } \\
\text { team to make clinic services } \\
\text { more accessible through mobile } \\
\text { vans, among others. }\end{array}$ \\
\hline Home-based & $\begin{array}{l}\text { Women who are identified to be } \\
\text { providing paid sexual services at a } \\
\text { specified place (could be lodge) and } \\
\text { operate through a pimp or manager using } \\
\text { the mobile telephone network within the } \\
\text { operational area are termed home-based } \\
\text { sex workers. }\end{array}$ & $\begin{array}{l}\text { Difficult to access, hidden high-risk FSWs who } \\
\text { most often live with their own families, who } \\
\text { are unaware of their profession. This secrecy } \\
\text { increases their vulnerability to harassment, } \\
\text { domestic violence from family members, } \\
\text { police, and local criminal elements. To maintain } \\
\text { their veiled existence, they are often forced } \\
\text { to offer free sexual favors to policemen, local } \\
\text { thugs, and politicians, affecting their condom- } \\
\text { negotiation power and putting them at high } \\
\text { risk of contracting STls and HIV. }\end{array}$ & $\begin{array}{l}\text { Development of strong support } \\
\text { groups, with a focus on crisis } \\
\text { response and group unity. } \\
\text { Training of peer educators to } \\
\text { maintain the confidentiality of the } \\
\text { FSWs' identities and tracking all } \\
\text { individual FSWs. } \\
\text { Networking with local service } \\
\text { providers as a long-term strategy. }\end{array}$ \\
\hline
\end{tabular}

Abbreviations: FSW, female sex worker; ATS, Aastha Tatkal Seva; HIV, human immunodeficiency virus; STI, sexually transmitted infection.

were chosen from the register using a systematic sampling procedure. The overall survey design, including sample-size calculation and participant recruitment, has been described in detail elsewhere. ${ }^{2}$ Interviews were conducted through a structured questionnaire by trained researchers in the local language (Hindi). The survey instrument was developed in English and translated into Hindi. The translated forms were reviewed by the study investigators, who were fluent in both English and Hindi. Field staff checked each questionnaire immediately after the interview to ensure accuracy and completion. Field supervisors reviewed the completed questionnaires on the same day, and these were sent every week to the data-management team for data entry. A user-written computer program in CSPro (version 4.0; US Census Bureau, Suitland, MD, USA) was used for double data entry by trained data-entry officers. Data were regularly processed to ensure consistency and accuracy.

\section{Ethical considerations}

The BTS was reviewed and approved by FHI 360's Protection of Human Subjects Committee, based in the US. A local community advisory board, functioning as the local institutional review board, including FSWs, FSW community based organizations (CBOs), and prominent researchers, was constituted in Mumbai, which worked closely with the local research agency and FHI 360 to ensure that the study participants' 
rights were protected. To protect confidentiality and respect privacy, all questionnaires were entirely anonymous, and names and addresses were not recorded. Oral consent was obtained from the respondents before they were interviewed to ensure they knew about the study and information sought from them. To maintain privacy, interviews were conducted at a location dependent on the preference of the respondent. Participants were not given any monetary compensation for their time given to the study, but were provided information on HIV programs in the area.

\section{Measures}

The factors of vulnerability used in the current analysis are based on program experience, anecdotal sharing from FSWs at the beginning of the project, and evidence from the literature. ${ }^{8-16}$ Figure 2 presents the factors that make FSWs vulnerable to HIV risk, the program strategies of Aastha that focused on the vulnerabilities of FSWs, and the outcome measures that were considered in the paper.

\section{Vulnerability index and duration in Aastha program}

The vulnerability index and duration in the Aastha program were the two key independent measures considered in this paper. The factors used to construct the vulnerability index were based on several items in the questionnaire, which included literacy (literate, can read and/or write; illiterate, cannot read or write), duration in sex work ( $3+$ years, $\leq 2$ years), mobility for sex work (nonmobile, did not travel for sex work; mobile, traveled for sex work), additional source of income other than sex work (yes/no), currently being in debt (yes/no), and having children (yes/no). Using these six factors, a vulnerability index was constructed, with scale values ranging from 0 to 6 . Those who were new to sex work ( $\leq 2$ years), were in debt, were illiterate, had no alternative source of income, were mobile for sex work and had children were considered vulnerable to HIV infection. Using a median split, the index score was further divided into two categories to construct degree of vulnerability, with three or more factors constituting high vulnerability and fewer than three factors constituting low vulnerability.

Duration in the Aastha project was measured by asking the participants how long they had been associated/registered with the Aastha program. The responses included: less than 6 months, 7 months to 1 year, and more than a year (a trichotomous variable). The responses were further grouped into two categories ( $\leq 1$ year and $>1$ year). Program clinic data showed that sex workers exposed to various project services for at least a year had reduced STI symptoms and improved

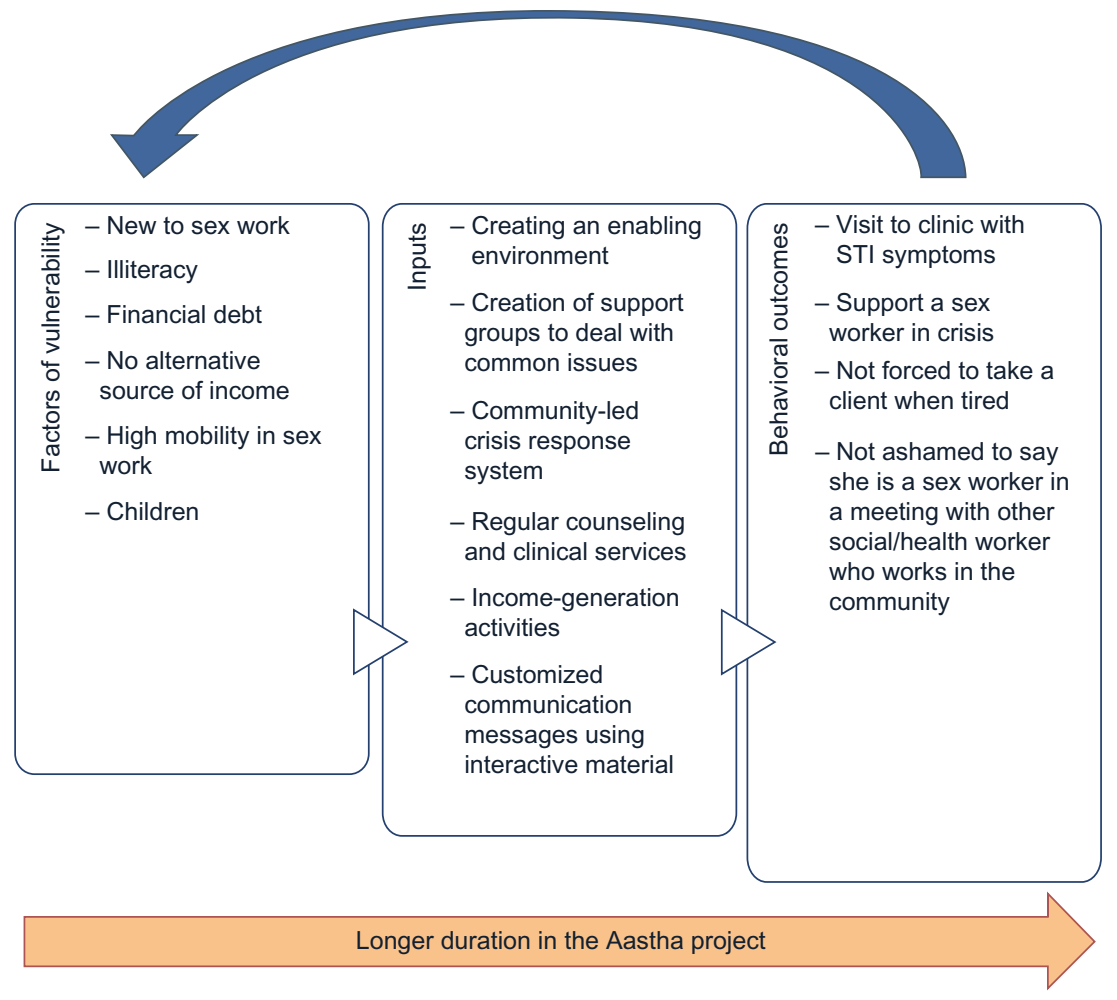

Figure 2 Longer program exposure of highly vulnerable female sex workers influences service uptake and behavior. Abbreviation: STI, sexually transmitted infection. 
health-seeking behavior. As a result, duration of participation was dichotomized as $\leq 1$ year versus $>1$ year.

\section{Program exposure and service utilization}

In the survey instrument, information was elicited on several dimensions of exposure to the Aastha program. The programexposure and service-utilization indicators considered in this paper were 1) received counseling/referral services from Aastha nongovernmental organizations in the last 6 months (yes/no), 2) aware of ATS (yes/no), 3) aware and accessed ATS services in the past 6 months (yes/no), and 4) visits to a clinic for STI symptoms in the past year. Visits to a clinic to check for STI symptoms was initially measured as a continuous variable by asking FSWs the number of times they visited the Aastha clinic, and was further dichotomized as "visited Aastha clinic to check for STI symptoms in the past year/did not visit Aastha clinic to check for STI symptoms".

\section{Self-confidence, self-identity, and individual agency}

Self-confidence was measured by asking each FSW 1) whether or not she was confident in supporting a fellow sex worker in crisis situation, and 2) whether or not she was confident in going to a service provider alone, where she may have to disclose her identity as a sex worker. Responses to these questions included: not at all, somewhat, very confident, and completely confident. FSWs who responded "very confident" or "completely confident" were considered confident. Both the aforementioned self-confidence measures were considered separately. The term "individual agency" was defined as each FSW's individual ability to make decisions herself. To measure FSWs' individual agency, a question was asked in the survey: How often do you take clients when you are tired? The responses included: never, sometimes, usually, and always. Those who responded "sometimes", "usually", and "always" were considered to be "taking clients" when they do not want to. The FSWs' ability to claim self-identity was measured by asking how much they agreed with the following two questions: whether they were not ashamed to say that they were a sex worker 1) in a meeting with other sex workers, and 2) when she met a social or health worker who worked in her community. The responses included: strongly agree, agree, disagree, and strongly disagree. Their responses were grouped into two categories: those who responded "strongly agree" and "agree" were considered as agreeing with the statement. The aforementioned two indicators for claiming identity were considered separately in this paper.

\section{Control variables}

In all our analyses, we controlled for age $(<25,25-29,30-34$, $35+$ years), marital status (ever married, never married), and typology of sex work (brothel-based, bar-based, street-/ home-/lodge-based).

\section{Statistical analyses}

Simple descriptive analyses were run on characteristics that were used to construct the vulnerability index. The relationship between selected sample characteristics and degree of vulnerability was assessed using $\chi^{2}$ contingency tables. A series of multivariate logistic regression models were constructed to examine the association between vulnerability, duration of exposure to the Aastha program, and FSWs' self-confidence, self-identity, individual agency, and service utilization, adjusting for age, marital status, and typology of sex work. All the analyses were performed using Stata 12 (StataCorp, College Station, TX, USA).

\section{Results}

Of the total analytical sample of 2,431 FSWs, 1,295 (53.3\%) were categorized as highly vulnerable. Table 2 describes the factors that were used to construct the vulnerability index. The literacy level was very low, with only a third $(29 \%)$ reporting that they could read or write, and nearly one in three reporting that they had children $(29 \%)$. A majority of the participants were new to sex work (81\%), with most (79\%)

Table 2 Sample characteristics that were used for constructing the vulnerability index among female sex workers in Mumbai and Thane, India, 2010-201।

\begin{tabular}{|c|c|c|}
\hline Background characteristics & $\mathbf{n}$ & $\%$ \\
\hline \multicolumn{3}{|l|}{ Literacy } \\
\hline Literate* & 708 & 29.1 \\
\hline Illiterate** & $\mathrm{I}, 723$ & 70.9 \\
\hline \multicolumn{3}{|l|}{ Duration of sex work } \\
\hline$\leq 2$ years & ।,965 & 80.8 \\
\hline$>2$ years & 466 & 19.2 \\
\hline \multicolumn{3}{|l|}{ Currently in debt } \\
\hline No & 1,825 & 75.1 \\
\hline Yes & 606 & 24.9 \\
\hline \multicolumn{3}{|l|}{ Mobility for sex work } \\
\hline Nonmobile & I,464 & 60.2 \\
\hline Mobile & 967 & 39.8 \\
\hline \multicolumn{3}{|l|}{ Have children } \\
\hline No & $\mathrm{I}, 704$ & 70.1 \\
\hline Yes & 727 & 29.1 \\
\hline \multicolumn{3}{|c|}{ Additional source of income other than sex work } \\
\hline Yes & 503 & 20.7 \\
\hline No & 1,928 & 79.3 \\
\hline
\end{tabular}

Notes: *Literate, can read and write; **illiterate, cannot read or write; "mobile, traveled for sex work; ${ }^{\#}$ nonmobile, did not travel for sex work. 
reporting it to be their main source of income. More than a third reported traveling for sex work (40\%), and nearly a quarter $(25 \%)$ were currently in debt.

As seen in Table 3, a higher proportion of FSWs who were in the age-group 18-25 years, who were never married (75.7\% versus $48.6 \%, P<0.001$ ), or who were bar-based sex workers were categorized as highly vulnerable to HIV risk compared to sex workers without these characteristics. Duration in the Aastha program was significantly associated with the degree of vulnerability. FSWs who had spent less than 1 year in the Aastha program were more likely to be highly vulnerable compared to those who had spent more than 1 year in the program $(63.9 \%$ versus $51.3 \%, P<0.001)$.

As seen in Table 4, highly vulnerable FSWs who were in the Aastha program for more than 1 year were more likely to be aware of ATS (adjusted odds ratio [OR] 2.4, 95\% confidence interval [CI] 1.4-4.0;P<0.001), to have accessed ATS services in the past 6 months (adjusted OR 2.2, 95\% CI 1.4-3.6; $P<0.001$ ), and to have visited an Aastha clinic to get a checkup for STI symptoms (adjusted OR 2.4, 95\% CI 1.2-4.8, $P<0.015$ ) compared to those less vulnerable with similar exposure to the Aastha program. Similarly, Table 5 indicates that a significantly higher proportion of highly vulnerable FSWs who were associated with or registered with the Aastha program for more than a year were not ashamed to disclose their identity as sex workers in a meeting with other

Table 3 Profile of the female sex workers (FSWs), duration of exposure to the Aastha program, and degree of vulnerability to human immunodeficiency virus risk in Mumbai and Thane, India, 2010-2011

\begin{tabular}{|c|c|c|c|c|}
\hline \multirow{2}{*}{$\begin{array}{l}\text { Background } \\
\text { characteristics }\end{array}$} & \multirow{2}{*}{$\begin{array}{l}\text { Total } \\
\text { sample }\end{array}$} & \multicolumn{3}{|c|}{ Degree of vulnerability } \\
\hline & & Low* (\%) & High $^{* *}(\%)$ & $P$-value \\
\hline \multicolumn{5}{|l|}{ Current age } \\
\hline Less than 25 years & 575 & 27.83 & 72.17 & \\
\hline $25-29$ years & 833 & 48.38 & 51.62 & $<0.001$ \\
\hline $30-34$ years & 555 & 51.17 & 48.83 & \\
\hline More than 35 years & 468 & 61.75 & 38.25 & \\
\hline \multicolumn{5}{|l|}{ Marital status } \\
\hline Ever married & 2,012 & 51.39 & 48.61 & $<0.001$ \\
\hline Never married & 419 & 24.34 & 75.66 & \\
\hline \multicolumn{5}{|l|}{ Typology\# } \\
\hline Brothel & 809 & 49.57 & 50.43 & $<0.001$ \\
\hline Bar & 806 & 39.7 & 60.30 & \\
\hline Street/home/lodge & 816 & 50.86 & 49.14 & \\
\hline \multicolumn{5}{|c|}{ Duration in Aastha program } \\
\hline$\leq \mathrm{I}$ year & 379 & 36.15 & 63.85 & $<0.001$ \\
\hline$>$ I year & 2,052 & 48.68 & 51.32 & \\
\hline
\end{tabular}

Notes: *Low vulnerability, fewer than three factors of vulnerability; **high vulnerability, three or more factors of vulnerability; "place where FSWs solicit clients; duration FSWs have been associated or registered with Aastha program. sex workers (adjusted OR 2.3, 95\% CI 1.2-3.6; $P<0.013$ ) and were not ashamed to disclose their identity as sex workers while meeting a health or social worker who worked in their community (adjusted OR 2.1, 95\% CI 1.2-3.5; $P<0.008$ ). Additionally, highly vulnerable FSWs with a longer association with the Aastha program were confident in supporting a fellow sex worker in crisis (adjusted OR 1.7, 95\% CI 1.0-2.8; $P<0.033$ ) compared to less vulnerable FSWs with similar exposure in Aastha program.

\section{Discussion}

The paper explores how FSW intervention programs can identify and assess vulnerabilities, and correspondingly can be used to design strategies. The findings show that those reporting higher vulnerability and who are exposed to project services for a longer period of time in Aastha are more likely to report a higher uptake of services and a higher degree of overall empowerment than those who are less vulnerable. This further illustrates the fact that project strategies of increasing awareness about services and risk over a period of time can lead to improved results. Creating mechanisms to address cases of harassment, violence, and other contingencies, and organizing FSWs in support groups has been pivotal in creating an enabling environment and challenging existing structures and power dynamics through empowered actions, ${ }^{19}$ such as disclosing their profession, effectively dealing with violence from stakeholders, and participating in friendly social interactions with peers outside of work contexts.

These findings corroborate similar studies that show that empowerment strategies are a critical pathway to risk reduction, in contrast to the standard "targeted intervention" approach. ${ }^{20}$ While the described behavioral outcomes and individual empowerment are desirable changes in the context of HIV intervention, structural intervention approaches typically create a collective identity among FSWs. ${ }^{7}$ Communityled structural intervention approaches, such as the ATS, are critical to the process of risk reduction. While the current paper focuses more on certain initiatives of the Aastha project, a more detailed analysis of community collectivization strategies has been described elsewhere. ${ }^{2}$

The results of the paper can be viewed in parallel with the findings of a study in Karnataka, which describes the use of similar strategies, among others, in influencing the context-specific social, economic, political, and environmental factors determining risk for HIV. ${ }^{9}$ It is critical to place the vulnerabilities of an individual FSW in context and to understand the complex interaction of various factors at 
Table 4 Association between degree of vulnerability, duration of exposure to Aastha program, and service uptake among female sex workers (FSWs) in Mumbai and Thane, India, 2010-201 I

\begin{tabular}{|c|c|c|c|c|c|c|}
\hline & \multicolumn{2}{|c|}{ Low vulnerability* } & \multicolumn{2}{|c|}{ High vulnerability** } & \multirow{3}{*}{$\begin{array}{l}\text { Vulnerability } \times \text { duration } \\
\text { of exposure to Aastha } \\
\text { program } \\
\text { AOR }(95 \% \mathrm{Cl})^{\ldots}\end{array}$} & \multirow[t]{3}{*}{$P$-value } \\
\hline & \multicolumn{4}{|c|}{ Duration of exposure to Aastha program } & & \\
\hline & $\begin{array}{l}<\text { I year } \\
\%(\mathbf{n})\end{array}$ & $\begin{array}{l}\text { I+ year } \\
\%(n)\end{array}$ & $\begin{array}{l}<\mathbf{l} \text { year } \\
\%(\mathbf{n})\end{array}$ & $\begin{array}{l}\text { I+ year } \\
\%(n)\end{array}$ & & \\
\hline Received counseling/referral services & $93.2(133)$ & $87.4(98 I)$ & $88.4(225)$ & $90.4(1,015)$ & $2.32(0.99-5.44)$ & 0.051 \\
\hline Aware of ATS & $75.9(137)$ & 68.9 (999) & $73.9(242)$ & $82.5(1,053)$ & $2.37(1.40-4.03)$ & 0.001 \\
\hline $\begin{array}{l}\text { Aware of ATS and accessed ATS services } \\
\text { in past } 6 \text { months }\end{array}$ & $67.9(137)$ & $60.9(999)$ & $64.5(242)$ & $74.8(1,053)$ & $2.23(1.37-3.6 \mid)$ & 0.001 \\
\hline $\begin{array}{l}\text { Accessed ATS and received support } \\
\text { from Aastha Gat (self-help group) }\end{array}$ & $56.9(137)$ & $55.8(999)$ & $57.4(242)$ & $66.5(1,053)$ & $1.54(0.97-2.44)$ & 0.068 \\
\hline $\begin{array}{l}\text { Visited clinic for STI symptoms in the } \\
\text { past year }\end{array}$ & $28.7(101)$ & $17.9(7 \mid 5)$ & I3.I (160) & I6.I (740) & $2.37(1.18-4.77)$ & 0.015 \\
\hline
\end{tabular}

Notes: *Low vulnerability, fewer than three factors of vulnerability; **high vulnerability, three or more factors of vulnerability; \#duration FSWs have been associated or registered with Aastha program; "\#model adjusted for age, marital status, and typology of sex work.

Abbreviations: AOR, adjusted odds ratio; Cl, confidence interval; ATS, Aastha Tatkal Seva; STI, sexually transmitted infection.

different levels, including economic, social, and politicolegal. For instance, an ethnographic case study of the Sonagachi HIV/ STD Intervention Project describes some of the factors contributing to HIV risk in the context of the brothel areas of Sonagachi, including the ambiguity of the legal status of the sex-work industry, lack of education, social discrimination, and occupational structures within the industry. ${ }^{7}$ Given the difficulty of "measuring" vulnerability, there is considerable lack of quantitative research, where a holistic definition of vulnerability has been used for the purpose of analysis. Hence, similar to the ethnographic study described earlier, the Aastha project also provides a useful construct by adapting a specific vulnerability index.
However, though the association of vulnerability index and behavior outcomes has important implications for HIV interventions, the results need to be seen in light of several limitations. First, this paper focuses on limited project services and desired behavior outcomes due to lack of relevant data, as it is drawn from the BTS, which had different objective and goals. Similar analyses in future should also include more comprehensive variables for their analyses, including the impact of high mobility, increased closure of bars due to police raids, consumption of alcohol amongst FSWs, and FSWs' economic status. Second, given that identifying sociocultural vulnerabilities is context-specific, the factors of vulnerability used for the current analysis are specific to

Table 5 Association between degree of vulnerability, duration of exposure to Aastha program, self-confidence, self-identity, and individual agency among female sex workers (FSWs) in Mumbai and Thane, India, 2010-20II

\begin{tabular}{|c|c|c|c|c|c|c|}
\hline & \multicolumn{2}{|c|}{ Low vulnerability* } & \multicolumn{2}{|c|}{ High vulnerability** } & \multirow{3}{*}{$\begin{array}{l}\text { Vulnerability } \times \\
\text { duration of exposure } \\
\text { to Aastha program } \\
\text { AOR }(95 \% \mathrm{CI})^{\# \#}\end{array}$} & \multirow[t]{3}{*}{$P$-value } \\
\hline & \multicolumn{4}{|c|}{ Duration of exposure to Aastha program } & & \\
\hline & $\begin{array}{l}<\text { I year } \\
\% \text { (n) }\end{array}$ & $\begin{array}{l}\text { I+ year } \\
\%(n)\end{array}$ & $\begin{array}{l}<\text { I year } \\
\%(n)\end{array}$ & $\begin{array}{l}\text { I+ year } \\
\%(n)\end{array}$ & & \\
\hline $\begin{array}{l}\text { Confident in supporting a fellow } \\
\text { sex worker in crisis }\end{array}$ & $70.8(137)$ & $71.5(999)$ & $63.2(242)$ & $76.0(1,053)$ & $1.72(1.04-2.82)$ & 0.033 \\
\hline $\begin{array}{l}\text { Confident in disclosing identity } \\
\text { to service provider }\end{array}$ & $67.9(137)$ & 79.9 (999) & $67.4(242)$ & $79.1(1,053)$ & $0.97(0.59-1.59)$ & 0.901 \\
\hline $\begin{array}{l}\text { Not ashamed to disclose identity as sex } \\
\text { worker in a meeting with other sex workers }\end{array}$ & $79.6(137)$ & 65.7 (999) & $77.3(242)$ & $77.6(1,053)$ & $2.34(1.16-3.58)$ & 0.013 \\
\hline $\begin{array}{l}\text { Not ashamed to disclose identity as sex } \\
\text { worker while meeting a health/social worker }\end{array}$ & $74.5(137)$ & $67.8(999)$ & $72.3(242)$ & $80.1(1,053)$ & $2.05(1.21-3.47)$ & 0.008 \\
\hline Does not take clients when she is tired & $86.1(137)$ & 81.6 (999) & $88.4(242)$ & $88.6(1,053)$ & $1.38(0.70-2.72)$ & 0.349 \\
\hline
\end{tabular}

Notes: *Low vulnerability, fewer than three factors of vulnerability; **high vulnerability, three or more factors of vulnerability; \#duration FSWs have been associated or registered with Aastha program; "\#model adjusted for age, marital status, and typology of sex work.

Abbreviations: $\mathrm{AOR}$, adjusted odds ratio; $\mathrm{Cl}$, confidence interval. 
the districts of Mumbai and Thane, but could be replicated with suitable adaptation in other parts of India and South Asian countries. Third, the responses of the FSWs were part of a larger study to assess the behavioral outcomes of FSWs across Mumbai and Thane, and not to attempt to define vulnerability and assess its association with project services or desired behavior outcomes. Finally, a lack of cohort data makes it difficult for the paper to establish causality between degree of vulnerability and the desired behavior outcomes or between the observed behavior changes and the community mobilization efforts. Further, longitudinal research is required to understand causality between these measures.

In summary, it is critical for HIV/STI interventions to identify and define factors of vulnerability at project inception, prior to developing risk-reduction strategies. The factors should be thoroughly and strategically addressed in program design and periodically reviewed to take into account changes in economic, social, and legal scenarios. Moreover, it is important to look at a holistic interaction of different sociocultural vulnerabilities, such as lack of education, poor economic status, financial debts, presence of dependants such as children, lack of other livelihood options, mobility due to sex work, and duration in sex work, as well as changes in the social and legal environment, which contribute towards an environment of increased violence and lack of individual agency and control, rather than just one or two factors. Though addressing structural barriers is a complicated and long-term process, it plays a critical role in reducing HIV risk amongst high-risk groups like FSWs. In summary, we would like to say that defining vulnerability and constructing a specific vulnerability index and assessing it in the context of behavioral outcomes and project inputs would create a better understanding of the effectiveness of HIV-prevention interventions with FSWs.

\section{Acknowledgments}

Since 2004, FHI 360 has been implementing the Aastha project with the goal of reducing the incidence of STIs and HIV among FSWs and their regular partners in the Mumbai and Thane districts of Maharashtra state in India. The authors wish to acknowledge the implementing partners and all the sex workers who participated in the study. The authors would also like to acknowledge the Bill and Melinda Gates Foundation, which has funded this project through Avahan, its India AIDS initiative. However, the views expressed herein are those of the authors, and do not reflect the official policy or position of the Bill and Melinda Gates Foundation or Avahan. Also, this paper was written as part of a mentorship program within the Knowledge Network Project coordinated by the Population Council, which is a grantee of the Bill and Melinda Gates Foundation through Avahan.

\section{Disclosure}

The authors report no conflicts of interest in this work.

\section{References}

1. Gupta GR, Parkhurst JO, Ogden JA, Aggleton P, Mahal A. Structural approaches to HIV prevention. Lancet. 2008;372(9640):764-775.

2. Gaikwad SS, Bhende A, Nidhi G, Saggurti N, Ranebennur V. How effective is community mobilisation in HIV prevention among highly diverse sex workers in urban settings? The Aastha intervention experience in Mumbai and Thane districts, India. $J$ Epidemiol Community Health. 2012;66 Suppl 2:ii69-ii77.

3. Gurung A, Narayanan P, Prabhakar P, et al. Large-scale STI services in Avahan improve utilization and treatment seeking behaviour amongst high-risk groups in India: an analysis of clinical records from six states. BMC Public Health. 2011;11 Suppl 6:S10.

4. Mishra RM, Dube M, Sahu D, Saggurti N, Pandey A. Changing epidemiology of HIV in Mumbai: an application of the Asian epidemic model. Glob J Health Sci. 2012;4(5):100-112.

5. Singer MC, Erickson PI, Badiane L, et al. Syndemics, sex and the city: understanding sexually transmitted diseases in social and cultural context. Soc Sci Med. 2006;63(8):2010-2021.

6. Delor F, Hubert M. Revisiting the concept of 'vulnerability'. Soc Sci Med. 2000;50(11):1557-1570.

7. Evans C, Jana S, Lambert $\mathrm{H}$. What makes a structural intervention? Reducing vulnerability to HIV in community settings, with particular reference to sex work. Glob Public Health. 2010;5(5):449-461.

8. Muñoz J, Adedimeji A, Alawode O. 'They bring AIDS to us and say we give it to them': socio-structural context of female sex workers' vulnerability to HIV infection in Ibadan, Nigeria. SAHARA J. 2010;7(2):52-61.

9. Gurnani V, Beattie TS, Bhattacharjee P, et al. An integrated structural intervention to reduce vulnerability to HIV and sexually transmitted infections among female sex workers in Karnataka state, south India. BMC Public Health. 2011;11:755.

10. Saggurti N, Jain AK, Sebastian MP, et al. Indicators of mobility, socioeconomic vulnerabilities and HIV risk behaviours among mobile female sex workers in India. AIDS Behav. 2012;16(4):952-959.

11. Population Council. Patterns of Migration/Mobility and HIV Risk among Female Sex Workers: Andhra Pradesh. New Delhi: Population Council; 2008.

12. Greener R, Sarkar S. Risk and vulnerability: do socioeconomic factors influence the risk of acquiring HIV in Asia? AIDS. 2010;24 Suppl 3: S3-S11.

13. Reed E, Gupta J, Biradavolu M, Devireddy V, Blankenship KM. The context of economic insecurity and its relation to violence and risk factors for HIV among female sex workers in Andhra Pradesh, India. Public Health Rep. 2010;125 Suppl 4:81-89.

14. Saggurti N, Verma RK, Halli SS, et al. Motivations for entry into sex work and HIV risk among mobile female sex workers in India. J Biosoc Sci. 2011;43(5):535-554.

15. Bowen KJ, Dzuvichu B, Rungsung R, Devine AE, Hocking J, Kermode M. Life circumstances of women entering sex work in Nagaland, India. Asia Pac J Public Health. 2011;23(6):843-851.

16. Ramesh S, Ganju D, Mahapatra B, Mishra RM, Saggurti N. Relationship between mobility, violence and HIV/STI among female sex workers in Andhra Pradesh, India. BMC Public Health. 2012;12:764.

17. Bharat S, Mahapatra B, Roy S, Saggurti N. Are female sex workers able to negotiate condom use with male clients? The case of mobile FSWs in four high HIV prevalence states of India. PLoS One. 2013;8(6):e68043. 
18. Nusbaum MR, Wallace RR, Slatt LM, Kondrad EC. Sexually transmitted infections and increased risk of co-infection with human immunodeficiency virus. J Am Osteopath Assoc. 2004;104(12):527-535.

19. Cornish F, Ghosh R. The necessary contradictions of 'community-led' health promotion: a case study of HIV prevention in an Indian red light district. Soc Sci Med. 2007;64(2):496-507.
20. Swendeman D, Basu I, Das S, Jana S, Rotheram-Borus MJ. Empowering sex workers in India to reduce vulnerability to HIV and sexually transmitted diseases. Soc Sci Med. 2009;69(8):1157-1166.

\section{Publish your work in this journal}

HIV/AIDS - Research and Palliative Care is an international, peerreviewed open-access journal focusing on advances in research in HIV, its clinical progression and management options including antiviral treatment, palliative care and public healthcare policies to control viral spread. The journal welcomes original research, basic science, clinical \& epidemiological studies, reviews \& evaluations, expert opinion \& commentary, case reports \& extended reports. The manuscript management system is completely online and includes a very quick and fair peer-review system. Visit http://www.dovepress.com/ testimonials.php to read real quotes from published authors.

Submit your manuscript here: http://www.dovepress.com/hivaids---research-and-palliative-care-journal 